九州大学学術情報リポジトリ

Kyushu University Institutional Repository

\title{
Salinity Tolerance of the Flounder, Paralichthys olivaceus Larvae with Growth
}

Mihelakakis, Apostolos

Fishery Research Laboratory, Faculty of Agriculture, Kyushu University

Kitajima, Chikara

Fishery Research Laboratory, Faculty of Agriculture, Kyushu University

https://doi.org/10.5109/24064

出版情報 : 九州大学大学院農学研究院紀要. 39 (1/2)，pp. 25-33，1994-12. Kyushu University バージョン：

権利関係 : 


\title{
Salinity Tolerance of the Flounder, Paralichthys olivaceus Larvae with Growth*
}

\author{
Apostolos Mihelakakis and Chikara Kitajima \\ Fishery Research Laboratory, Faculty of Agriculture, \\ Kyushu University, Fukuoka 811-33, Japan \\ (Received July 20, 1994)
}

\begin{abstract}
Flounder, Paralichthys olivaceus larvae of different ages (1, 9, 18 and 27 days after hatching) were exposed for $120 \mathrm{~h}$ under food deprivation at various salinities $(0,4,8,12,16$, 20, 32, 36, 40, 44, 48 and 52). Mortalities were recordid every $24 \mathrm{~h}$. Salinity levels at which $50 \%$ larvae survived over the entire test period $(120 \mathrm{~h})$ were $16-36$ for 1-day-old larvae, 16 and 20 for 9-day-old, 8-32 for 18-day-old and 8-20 for 27-day-old larvae. The greatest overall survival was recorded at 16 for 1 and g-day-old larvae and 12 for 18 and 27-day-old larvae.

The results suggest that flounder larvae can better withstand abrupt decrease rather than increase in salinity below ambient levels, and that the salinity tolerance of the larvae varies with age and exposed time.
\end{abstract}

\section{INTRODUCTION}

Knowledge of tolerance limits of marine fish larvae to different salinities is of ecological significance in assessing larval distribution and their impact on ecosystems. Limiting levels of natural environmental circumstances can induce sublethal responses in fish eggs and larvae (Rosenthal and Alderdice, 1976). Such responses may also occur when alteration of natural environmental factors is induced on a local scale by man's activities (hydroelectric dams, power and desalination plants, etc.). The effects of salinity during this period of ontogeny are also crucial to the development of hatchery procedures.

Little information is available on salinity tolerances of early life stages of the Japanese flounder, Paralichtys olivaceus (Yasunaga, 1975 ; Yasunaga and Koshiishi, 1980). These studies refer to short-time exposure $(24 \mathrm{~h})$ of larvae and juveniles in different salinities and temperatures. The effect of salinity on growth of posthatched larvae and on their survival after metamorphosis has been investigated by $\mathrm{Oh}$ et al. (1994).

The present study was conducted to determine the salinity tolerance of the Japanese flounder larvae at different developmental stages, in laboratory conditions, and to establish the optimal salinity range for their maintenance.

\footnotetext{
* Contribution from Fish. Res. Lab., Kyushu University, No 197
} 


\section{MATERIALS AND METHODS}

\section{Fertilization and larval rearing}

Naturally fertilized eggs of flounder were obtained from a broodstock held in captivity. The broodstock consisted of one female and two males. After the eggs were washed and put in a measuring cylinder, a number of about 50000 buoyant eggs with a mean diameter of $0.883 \pm 0.022 \mathrm{~mm}$ was separated and transferred into an indoor 1- $\mathrm{m}^{3}$ polycarbonate tank. The larvae were fed for 3-15 days after hatching with rotifers, Brachionus plicatilis, cultured with Nannochloropsis sp. From day 12 to 27 after hatching they were fed with Artemia nauplii enriched for 20 hours with n-3 HUFA, the essential fatty acids for marine fish (Watanabe et al. 1983). Larvae were reared at ambient temperature and salinity. Water temperature during the rearing period ranged from 16.3 to $19.2^{\circ} \mathrm{C}$ with a mean value of $17.4^{\circ} \mathrm{C}$. Salinity ranged from 28.9 to 30.7 . The tank was illuminated with fluorescent lamp and a photoperiod 12-12 h light-dark was used. Light intensity at the water surface was about 800 lux.

\section{Experimental procedure}

Salinity and temperature were measured on a Merbaru NS-3P salinometer. Salinity tolerance was determined by exposing larvae of different developmental stages to a test salinity, and recording mortalities periodically during the test period. Forty-eight groups of salinity challenge tests were carried out at various times from April 28 to May 28, 1993, in conjunction with the developmental stage of the larvae. The experiments on salinity tolerance were carried out in $1 l$ Pyrex beakers. The terminology of Seikai et al. (1986) is used to describe the developmental stages of $P$. olivaceus that were exposed to salinity tests (Table 1). Larvae of 1, 9, 18 and 27 days old ( $\mathrm{H} 1, \mathrm{H} 9, \mathrm{H} 18$ and $\mathrm{H} 27$ respectively) were transferred directly from the rearing tank and were exposed for $120 \mathrm{~h}$ in salinities of $0,4,8,12,16,20,32,36,40,44,48$ and 52.

Salinities were made up by diluting sea water with tap water, or by adding artificial sea salt "Sea Life" (Marintech Co.) to sea water. A total number of 30 larvae that were regarded as normal in appearance and behavior was stocked in each beaker. There was no water replacement nor feeding during the test period. To minimize evaporation, beakers were covered with loose fitting plastic tops. Temperature was maintained at $19.0 \pm 1.0^{\circ} \mathrm{C}$. Beakers were supplied with constant aeration. Mortalities were determined in each beaker at $24,48,72,96$, and $120 \mathrm{~h}$ exposures. Dead

Table 1. Developmental stages and morphological characteristics of flounder larvae exposed to various salinity levels.

\begin{tabular}{rllc}
\hline $\begin{array}{l}\text { Age in } \\
\text { days }\end{array}$ & Developmental stages & Main characteristics of stages & $\begin{array}{c}\text { Mean total } \\
\text { length (mm) }\end{array}$ \\
\hline 1 & Prelarval period : PL & Yolk sac larvae & \\
9 & Postlarval period : B & Bud of elongate anterior dorsal fin rays & 5.15 \\
18 & Postlarval period : E & Notochord flexed upward (45”) & 9.73 \\
27 & Postlarval period : G & Right eye observable from left side & 14.08 \\
\hline
\end{tabular}


larvae deposits and faeces were removed by siphoning. The criterion of tolerance adopted was that $50 \%$ of the larvae should survive for the given time in the test salinity.

\section{RESULTS}

The behavior of the newly hatched larvae depended on the salinity. Larvae exposed at the lowest salinities ( 0 and 4$)$ were motionless at the bottom of the beakers. At 48 and 52 they were floating near the surface of the water. The most active larvae were observed at salinities of 20-36.

Cumulative survival is shown in Figures 1 to 4 . The greatest overall survival was recorded at 16 for $\mathrm{H} 1$ and $\mathrm{H} 9$ larvae and at 12 for $\mathrm{H} 18$ and $\mathrm{H} 27$ larvae.

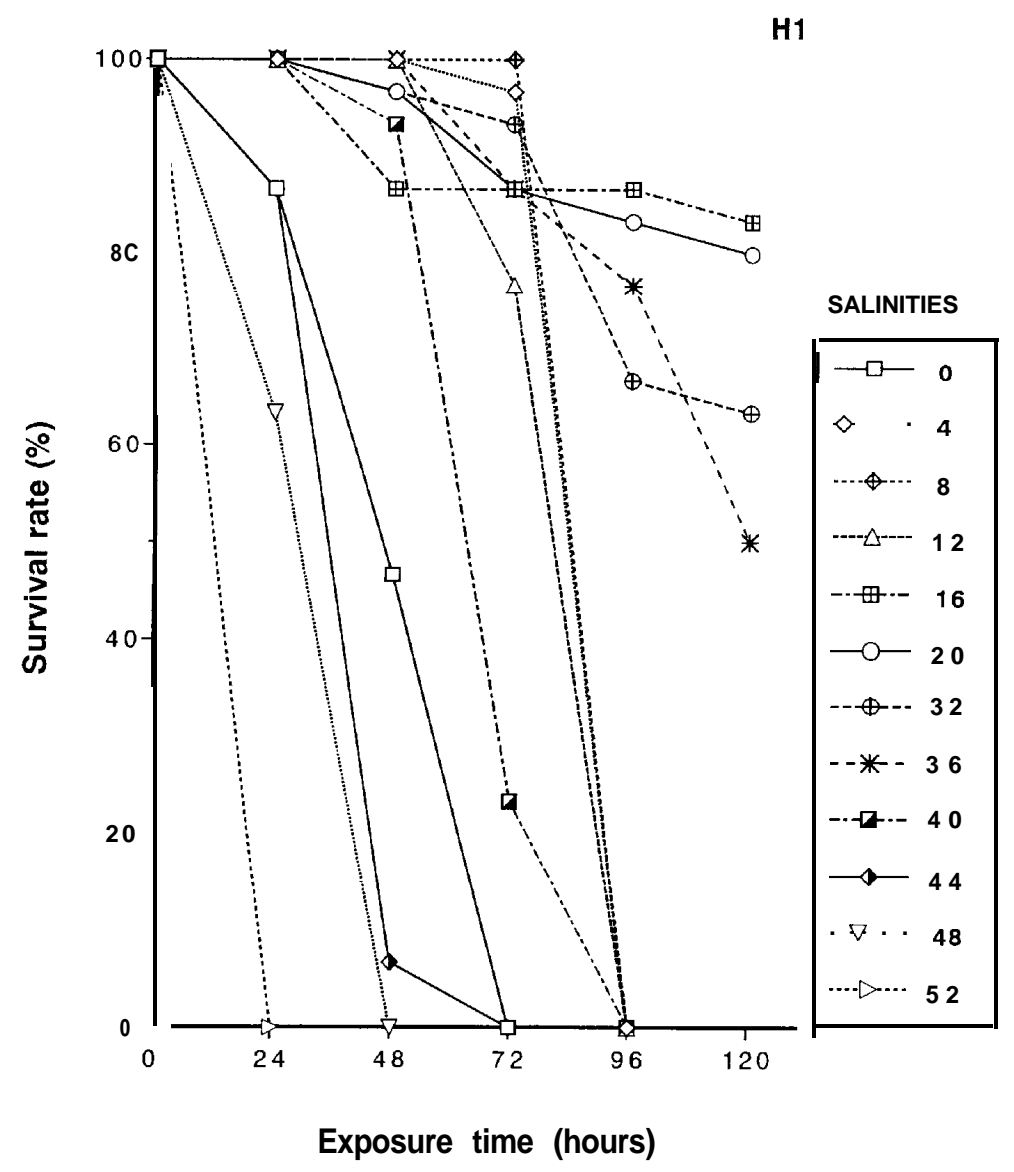

Fig. 1. Cumulative survival of 1-day-old flounder larvae exposed for $120 \mathrm{~h}$ at different salinities, under food deprivation. 


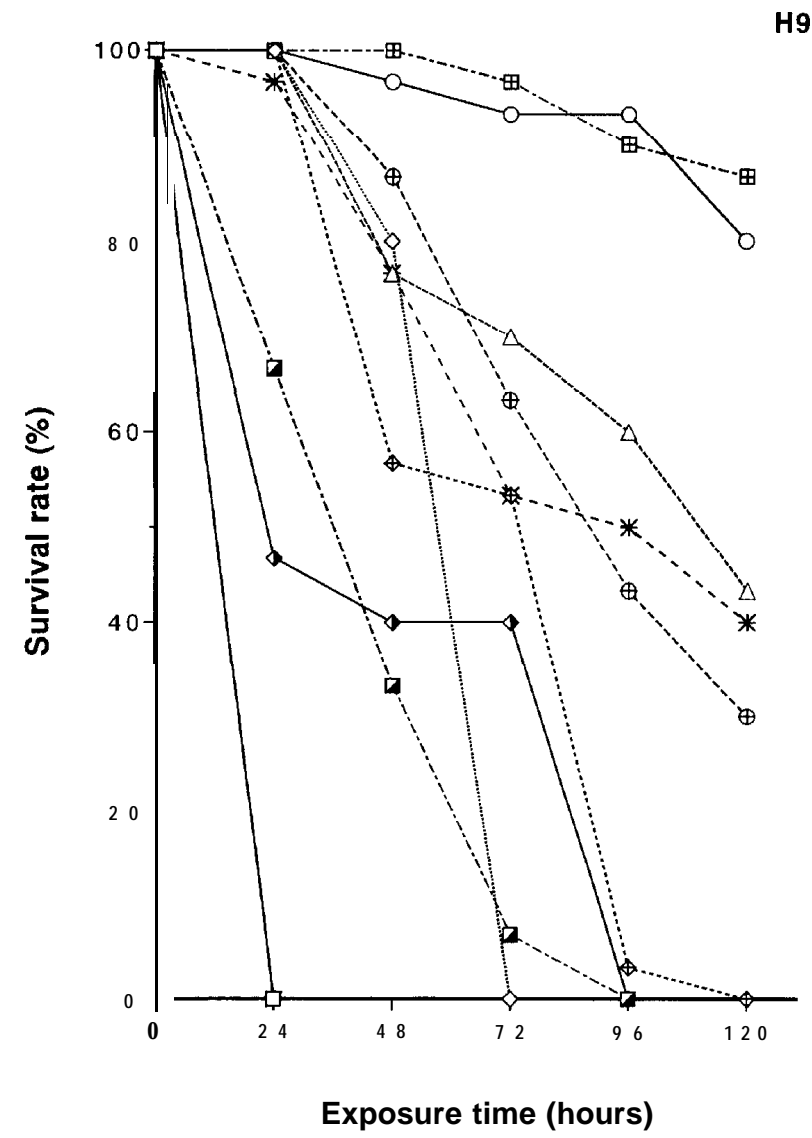

Fig. 2. Cumulative survival of S-day-old flounder larvae exposed for $120 \mathrm{~h}$ at different salinities, under food deprivation. Salinity symbols of 0,48 and 52 are overlapped.

Salinity tolerance of the larvae is shown in Fig. 5. Based of the criterion of tolerance it was found that salinity of 52 is hazardous for P.olivaceus larvae. Salinities of 0,44 and 48 were tolerated for $24 \mathrm{~h}$ only by yolk-sac larvae (H1). After $120 \mathrm{~h}$ exposure, H1 larvae were able to tolerate salinities of $16-36, \mathrm{H} 9$ of 16 and 20, H18 of 8 to 32 and $\mathrm{H} 27$ salinities of 8 to 20 . The best performance about the width of salinity was achieved by the H18 larvae.

\section{DISCUSSION}

Marine fish larvae can tolerate a wide range of salinity in the early posthatching stages (Holliday, 1965, 1969) . The ability of the larvae to survive changes of salinity 


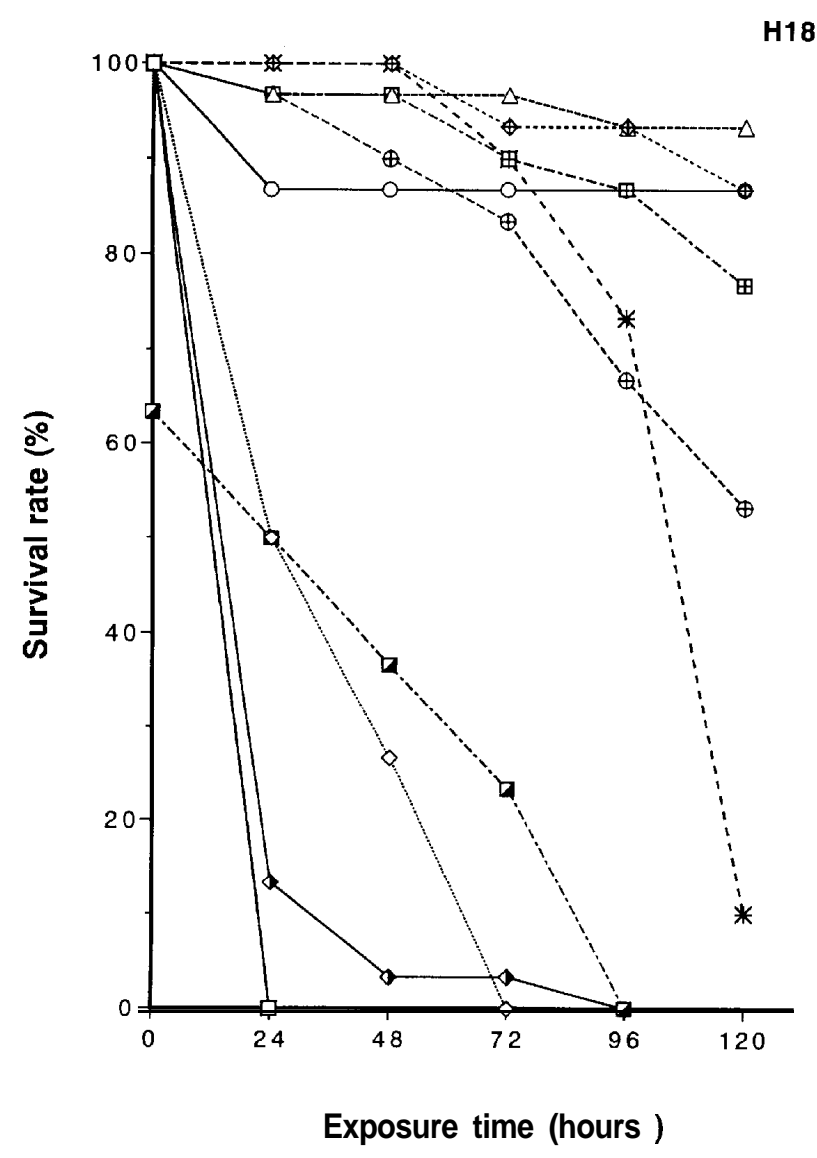

Fig. 3. Cumulative survival of 18-day-old flounder larvae exposed for $120 \mathrm{~h}$ at different salinities, under food deprivation. Salinity symbols of 0,48 and 52 are overlapped.

depends on either or both of two factors, first, the ability of the body fluids to function at least for a short time in an abnormal range of internal osmotic and ionic concentrations, and, second, the ability of the larvae to regulate the body fluids in order to restore the levels of osmotic pressure to near normal (Holliday, 1969).

The results of this study suggest that flounder, P.olivaceus larvae of 1-27 days old can better withstand abrupt decrease rather than increase in salinity below ambient levels, and that the salinity tolerance of the larvae varies with age and with the exposed time. 1-day-old larvae (H1) exhibit tolerance to a very wide range of salinity $(0-48$ for $24 \mathrm{~h})$. After $120 \mathrm{~h}$, larvae presented the highest survival rates at 12 and 16 . It has been shown that newly hatched fish larvae living in sea water have body fluids with a concentration equivalent to salinity of about 12-15 (Holliday and Blaxter, 1960 ; Holliday, 1971 ; Tytler and Blaxter, 1988). Within the salinity range 12-16 larvae 


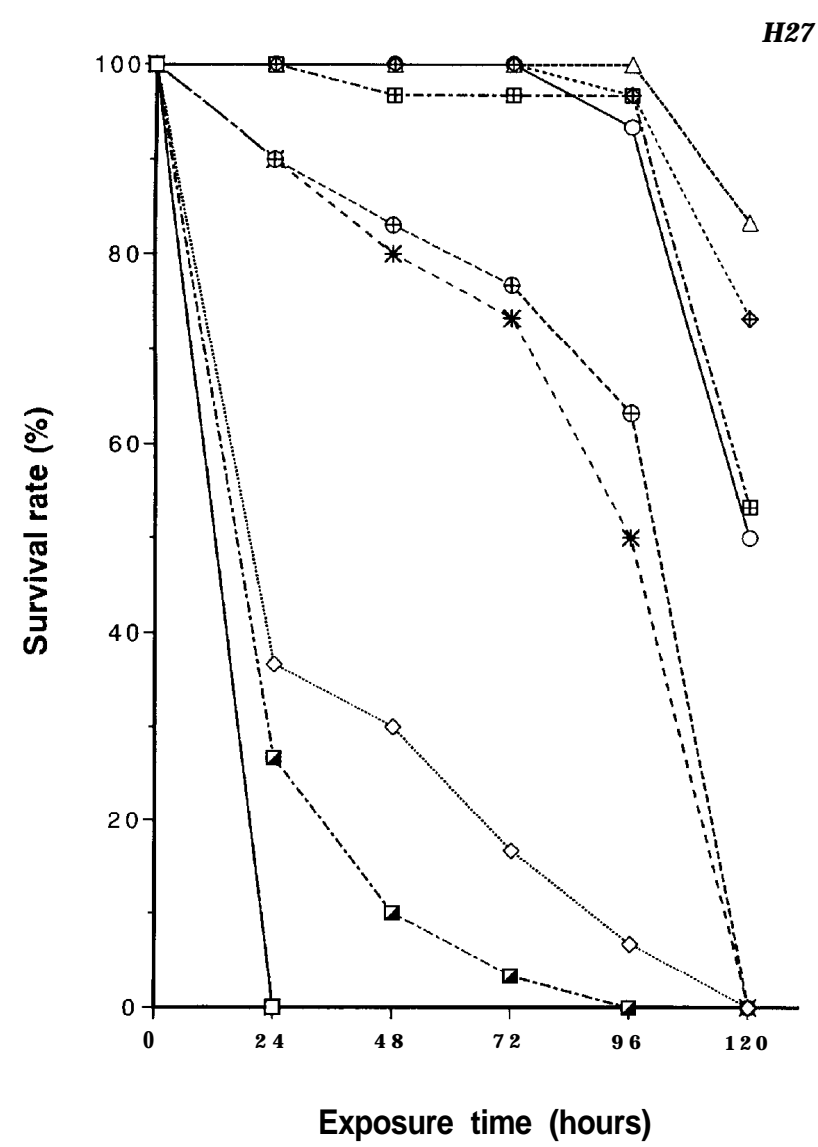

Fig. 4. Cumulative survival of 27 -day-old flounder larvae exposed for $120 \mathrm{~h}$ at different salinities, under food deprivation. Salinity symbols of $0,44,48$ and 52 are overlapped.

does not have to spend much energy for osmoregulation. According to Holliday (1969), increased survival in lower salinities could also be due to lower activity level of larvae resulting in less energy expenditure.

Herring, Clupea pallasi and C. harengus yolk-sac larvae can withstand external salinities ranging from 1-4 to 60-65 for $24 \mathrm{~h}$ (Kurata, 1959 ; Holliday and Blaxter, 1960) and $\mathrm{C}$. harengus have a slightly reduced range of tolerance over longer periods, up to $168 \mathrm{~h}$ (Holliday and Blaxter, 1960). Herring, C. harengus, and cod, Gadus callarias (Holliday, 1965) as well as plaice, Pleuronectes platessa (Holliday, 1965 ; Holliday and Jones, 1967) yolk-sac larvae are capable of withstanding a wide range of salinities for the test periods of up to 7 days (1-4 to 55-60 for herring, 5-15 to 60-65 for plaice, 10 -15 to 60 for cod). This wide range of tolerance could be due to low permeability in larvae attributed the structure and composition of the integument (Holliday, 1969) . In 


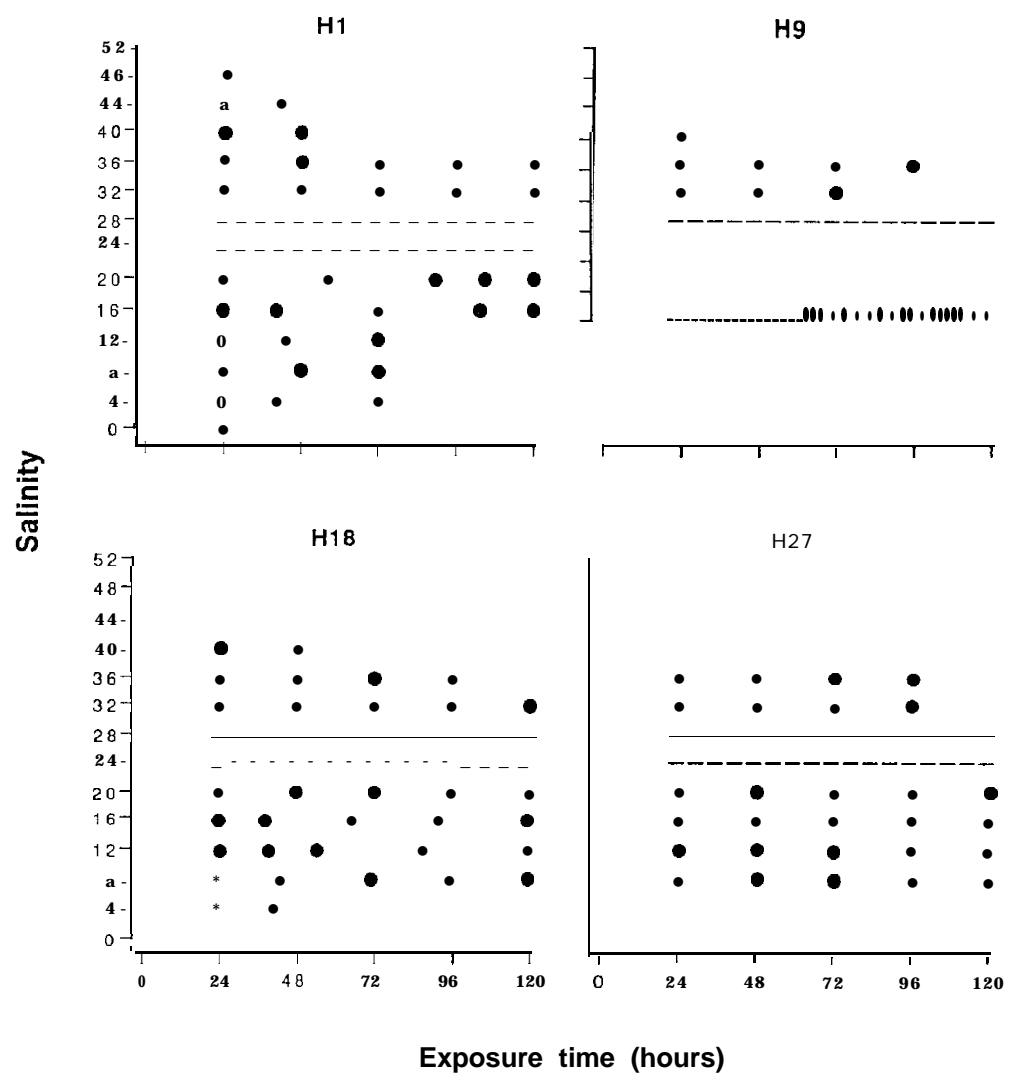

Fig. 5. Salinity tolerance of 1-day-old (H1), S-day-old (H9),18-day-old (H18) and 27-day-old (H27) flounder larvae under food deprivation. Each point is the salinity at which $50 \%$ of larvae survived from the initial stocking number, at intervals of $24 \mathrm{~h}$. Salinities of 24 and 28 were not tested.

sea bass, Dicentrarchus labrax, the survival of larvae increased when ambient salinity (38) was reduced at 10 and 20 (Johnson and Katavic, 1986). In the case of tropical marine fish, the rabbitfish, Siganus guttanus, at $12 \mathrm{~h}$ and $24 \mathrm{~h}$ post-hatch exhibits tolerance to a range of salinity from 10 to 45 and 14 to 37 , respectively (Young and Duenas, 1993). The milkfish, Chanos chanos, can tolerate a slightly wider range of salinity, from 8 to 37, following direct transfer from 32 at hatching (Duenas and Young, 1983). Investigations in groupers, Epinephelus malabaricus (Parado-Estepa, 1991) and E. tauvina (Akatsu et al. 1983), showed that newly-hatched larvae could best adapt in brackish water, particularly to salinities of 8 to 24 . Sylvester et al. (1975) reported that over the range of salinity 24-36 optimal larval survival of the grey mullet, Mugil cephalus, was recorded from 26-28 although short-term survival $(24 \mathrm{~h})$ was better than $80 \%$ over the entire range of $24-36$. For the same species, Hu and Liao, (1981) 
observed that different salinities seemed to have rather limited effect on larval survival during the first day, but after 2 days, in salinities over 23 survival decreased as the salinity increased.

Optimal larval survival at salinities less than the salinity at spawning provides evidence of adaptation of the larvae of the Japanese flounder for coastal and/or estuarine existence. It has been reported that an inshore movement takes place during the period of the pelagic larval stage of the flounder (Minami, 1982).

Apart from their ecological interest, the experimental results obtained in this study along with those reported by Oh et al. (1994) are of value for applied Ichthyology. Better performance of the larvae in salinities lower than that of sea water suggest that present larval rearing techniques, which employ sea water during the hatchery rearing of this species, may have to be modified. Larval flounder survival can be increased by culturing them in dilute sea water.

\section{REFERENCES}

Akatsu, S., K. M. Al Abdul Elah and S. K. Teng 1983 Effects of salinity and water temperature on the survival and growth of brown-spotted grouper larvae (Epinephelus tauvina, Serranidae). J. World Maricult. Soc., 14: 624-635

Duenas, C. E. and P. S. Young 1983 Salinity tolerance and resistance of milkfish larvae. Paper presented during the Second International Milkfish Aquaculture Conference, 4-8 October 1983, Iloilo, Philippines, Abstracts, p. 22

Holliday, F. G. T. 1965 Osmoregulation in marine teleost eggs and larvae. Calif. Coop. Oceanic Fish. Invest. Rep., 10: 89-95

Holliday, F. G. T. 1969 The effects of salinity on the eggs and larvae of teleosts. In "Fish Physiology", Vol. I, ed. by W. S. Hoar and D. J. Randall, Academic Press, New York, pp. 293-310

Holliday, F. G. T. 1971 Salinity. In "Marine Ecology" , Vol. I, Part 2, Wiley-Interscience, London, pp. $997-1077$

Holliday, F. G T. and J. H. S. Blaxter 1960 The effects of salinity on the developing eggs and larvae of the herring. J. Mar. Biol. Assoc. UK, 39: 591-603

Holliday, F. G. T. and M. P. Jones 1967 Some effects of salinity on the developing eggs and larvae of the plaice (Pleuronectes platessa).J. Mar. Biol. Assoc. UK, 47: 39-48

Hu, F. and I-C. Liao 1981 The effect of salinity on the eggs and larvae of grey mullet, Mugil cephalus. Rapp. P-v. Reun. Cons. int. Explor. Mer, 178: 460-466

Johnson, D. W. and I. Katavic 1986 Survival and growth of sea bass (Dicentrarchus labrax) larvae as influenced by temperature, salinity, and delayed initial feeding. Aquaculture, 52: 11-19

Kurata, H. 1959 Preliminary report on the rearing of the herring larvae. Bull. Hokkaido Reg. Fish. Res. Lab., 20: 117-138

Minami, T. 1982 The early life history of a flounder Paralichthys olivaceus. Bull. Jpn.Soc.Sci. Fish., 48: 1581-1588

Oh, K., S. Matsui and C. Kitajima 1994 Effect of salinity on the occurance of albinism in the laboratory-reared flounder. Paper presented during the First Korea-Japan Joint Meeting and Sumposium on Aquaculture, 20-22 May 1994, Cheju National University, Korea, Abstracts, p. 22

Parado-Estepa, F. D. 1991 Survival of newly-hatched larvae of Epinephlus malabaricus at different salinities. In "Larvi '91-Fish and Crustacean Larviculture Symposium", ed. by P. Lavens, P. Sorgeloos, E. Jaspers and F. Ollevier, European Aquaculture Society, Special Publication No 15, Gent, Belgium, pp. 323-325

Rosenthal, H. and D. F. Alderdice 1976 Sublethal effects of environmental stressors, natural and pollutional, on marine fish eggs and larvae. J. Fish. Res. Board Can., 33 :2047-2065

Seikai, T., J. B. Tanangonan and M. Tanaka 1986 Temperature influence on larval growth and 
metamorphosis of the Japanese flounder Paralichthys olivaceus in the laboratory. Bull. Jpn.Soc. Sci. Fish., $52: 977-982$

Sylvester, J. R., C. E. Nash and C. R. Emberson 1975 Salinity and oxygen tolerances of eggs and larvae of Hawaiian striped mullet, Mugil cephalus L. J. Fish Biol., 7: 621-629

Tytler, P. and J. H. S. Blaxter 1988 The effects of external salinity on the drinking rates of the larvae of herring, plaice and cod. J. Exp. Biol., $138: 1-15$

Yasunaga, Y. 1975 Effect of water temperature and salinity on the embryonic development of eggs and the survival of larvae of Paralichthys olivaceus. Bull. Tokai Fish Res. Lab., 81: 151-162

Yasunaga, Y. and Y. Koshiishi 1980 Basic studies of problems on the propagation of plaice, Paralichthys olivaceus. Bull. Jap.Sea Reg. Fish. Lab., $31: 17-31$

Young, P. S. and C. E. Duenas 1993 Salinity tolerance of fertilized eggs and yolk-sac larvae of the rabbitfish Siganus guttanus (Bloch). Aquaculture, 112 : 363-377

Watanabe, T., T. Tamiya, A. Oka, M. Hirata, C. Kitajima and S. Fujita 1983 Improvement of the dietary value of live foods for fish larvae by feeding them $\omega 3$ higly unsaturated fatty acids and fat-soluble vitamins. Bull. Jpn. Soc.Sci. Fish., 49:471-479 